TRIADIK

ISSN (print): 0853-8301; ISSN (online): 2745-777X

Available online at https://ejournal.unib.ac.id/index.php/triadik

DOI: https://doi.org/10.33369/triadik.v19i1.16460

page: $11-18$

\title{
PENGARUH BIMBINGAN KELOMPOK BERBASIS CYBER- GUIDANCE UNTUK MENCEGAH PEMBELIAN IMPULSIF DI INSTAGRAM PADA MAHASISWA
}

\author{
Radha Dinda Agisni, Yessy Elita, Vira Afriyati \\ Universitas Bengkulu
} Korespondensi: $\frac{\text { Radhadinda222@gmail.com, yessyelita@unib.ac.id, }}{\text { vira@konselor.org }}$

\begin{abstract}
Abstrak
Penelitian ini bertujuan untuk mendeskripsikan bagaimana pengaruh layanan bimbingan kelompok berbasis Cyber-guidance terhadap pembelian impulsif di Instagram pada mahasiswa semester 5B Program Studi Bimbingan dan Konseling Universitas Bengkulu. Penelitian ini menggunakan metode eksperimen one group pre-test and post-test. Sampel penelitian ini adalah 7 orang mahasiswa semester 5B Program Studi Bimbingan dan Konseling Universitas Bengkulu. Teknik pengumpulan data menggunakan angket dengan skala Likert. Teknik analisis data yang digunakan adalah uji t. Hasil penelitian menunjukkan bahwa tingkat pembelian impulsif menurun setelah diberikan layanan, hal ini ditunjukkan dengan nilai $\mathrm{t}=9.744$ dan $\mathrm{p}=0.000$ maka $\mathrm{p}<0.05$. Sehingga $\mathrm{H} 0$ ditolak dan Ha diterima. Artinya ada penurunan pembelian impulsif sebelum dan setelah diberikan bimbingan kelompok dengan teknik scalling.
\end{abstract}

Kata Kunci: cyber-guidance, layanan bimbingan kelompok, pembelian impulsif

\begin{abstract}
The purpose of this study was to describe the influence of group guidance service based on cyber-guidance via WhatsApp with scalling technique to prevent impulsive buying on Instagram in $5^{\text {th }}$ Semester student of Guidance and counseling Study Program in University of Bengkulu. The method in this research is a method of experimentation with approaches preExperimental design. An alternative approach used was the one group pretest post-test design. Sampling used a purposive sampling technique. The number of samples are 7 students of B Class in $5^{\text {th }}$ Semester. This research data is analyzed using t-test. The result showed that the impulsif buying was decreased after given group guidance based on cyber-guidance via WhatsApp, this is indicated by the value of $t=9.744$ and shows zig mark 0.000. This finding that there is an influence of group guidance service based on cyberguidance to decrease impulsive buying in students of Guidance and counseling Study Program in University of Bengkulu
\end{abstract}

Keywords: cybercounseling, group counseling, impulsive buying, 


\section{Pendahuluan}

Pembelian impulsif menurut Rook dapat diartikan sebagai suatu perilaku pembelian yang tidak direncanakan, dilakukan berdasarkan spontanitas, serta dilakukan langsung di tempat, diikuti oleh keinginan kuat dan perasaan nikmat dan senang (dalam Widawati, 2011). Arnould (dalam Sari \& Faisal, 2018) mengatakan bahwa pembelian impulsif merupakan suatu pembelian yang terjadi ketika seseorang melihat suatu barang dan tiba-tiba ingin membeli barang tersebut dan kemudian memutuskan untuk melakukan pembelian pada saat itu juga. Dua pernyataan di atas memberikan kesimpulan bahwa pembelian impulsif ini merupakan pembelian yang dilakukan tanpa didasari oleh kebutuhan dan bersifat spontanitas.

Salah satu faktor yang dapat mempengaruhi pembelian impulsif adalah promosi barang (Miranda, 2016). Saat ini konsumen bisa melihat promosi barang kapan dan dimana saja termasuk di media sosial. Salah satu media sosial yang memuat promosi barang adalah Instagram. Instagram sendiri dapat memuat promosi barang melalui endorsement artist, iklan stories, dan melalui akun online shop. Pada masa pandemi seperti sekarang ketika PSBB (Pembatasan Sosial Berskala Besar) diberlakukan menyebabkan terbatasnya aktivitas fisik dan meningkatnya akses media sosial, termasuk Instagram. Semakin sering seseorang mengakses Instagram maka semakin sering pula seseorang melihat promosi barang. Dengan tersedianya promosi penjualan konsumen akan lebih banyak menerima informasi mengenai sebuah produk dan akhirnya melakukan keputusan pembelian (Rook, 1987).

Pembelian impulsif secara online sangat potensial dilakukan oleh konsumen di masa sekarang (Rook \& Fisher, 1995). Ketersediaan internet dengan kepraktisannya ini menjadi akses utama bagi konsumen untuk melakukan pembelian impulsif (Rook \& Fisher, 1995).

Hasil penelitian oleh Indika dan Jovita mengenai promosi Floating Market, salah satu destinasi pariwisata di Bandung, membuktikan bahwa media sosial Instagram yang menonjolkan sharing foto atau gambar terbukti mempunyai korelasi kuat dalam mempengaruhi minat beli konsumen di sana (Indika \& Jovita, 2017). Minat beli konsumen terutama oleh remaja di Instagram kerap tidak didasari oleh kebutuhan (Fitriyani et al., 2013). Mahasiswa yang masih merupakan remaja akhir juga seringkali melakukan pembelian impulsif.

Pembelian impulsif akan memberikan beberapa dampak negatif bagi pelakunya. Menurut Rook dan Hoch ada beberapa dampak pembelian impulsif, antara lain berkurangnya keuangan pribadi, kepuasan pasca pembelian, dan dapat mempengaruhi self-esteem (Rahman Afandi \& Hartati, 2017). Penyesalan setelah pembelian pada umumnya terjadi setelah pembeli menyadari bahwa produk yang dibelinya tidak terlalu dibutuhkan. Berkurangnya keuangan, karena pembelian impulsif merupakan pembelian yang tidak direncanakan maka pembelian impulsif ini menggunakan uang yang sudah dialokasikan oleh seorang individu untuk kebutuhan yang lain. Sehingga pembelian impulsif ini dapat mengakibatkan tidak terpenuhinya kebutuhan-kebutuhan individu yang apabila tidak dicegah dapat menimbulkan sebuah permasalahan baru.

Layanan bimbingan kelompok dapat digunakan untuk mencegah pembelian impulsif. Layanan bimbingan konseling dapat dilakukan secara tatap muka maupun menggunakan perantara media elektronik (Ifdil \& Ardi, 
2013). Hal ini dilakukan untuk mempermudah serta untuk meningkatkan mutu pelaksanaan layanan yang berkembang mengikuti kemajuan teknologi.

Penggunaan layanan bimbingan secara cyber-guidance via WhatsApp dipilih karena kemudahan dan fleksibilitasnya sehingga mahasiswa dapat melakukan layanan bimbingan kelompok dimana saja tanpa terkendala batas waktu. Meskipun sedang diberlakukan PSBB (Pembatasan Sosial Berskala Besar) layanan ini masih dapat dilakukan mengingat layanan ini menggunakan perantara elektronik. Hal ini juga dapat mencegah penyebaran virus Covid-19. WhatsApp yang menjadi media sosial yang dipilih karena itu merupakan media komunikasi yang biasanya digunakan oleh mahasiswa. Penelitian menggunakan perantara media elektronik dapat dikatakan efektif sebagaimana pelaksanaan layanan konvensional tatap muka. Puspita (Puspita et al., 2019) dalam penelitiannya memberikan layanan secara cybercounseling terbukti mampu meningkatkan keterbukaan diri mahasiswa.

Berdasarkan uraian latar belakang yang telah dipaparkan, penulis bertujuan menguji "Pengaruh layanan Bimbingan Kelompok berbasis CyberGuidance melalui WhatsApp untuk mencegah perilaku Pembelian impulsif Online di Instagram pada mahasiswa semester 5B Program Studi Bimbingan dan Konseling Universitas Bengkulu"

\section{Metode Penelitian}

Desain penelitian merupakan rancangan bagaimana penelitian ini akan dilaksanakan. Penelitian ini menggunakan One Group Pre-test-post-test design. Penelitian ini digunakan untuk mengetahui adanya pengaruh suatu tindakan terhadap suatu variabel. Variabel yang digunakan untuk memprediksi disebut variabel bebas. Variabel yang yang diprediksi disebut variabel terikat. Variabel bebas pada penelitian ini yaitu bimbingan kelompok dengan teknik scalling sedangkan variabel terikatnya adalah pembelian impulsif. Teknik pengambilan sampel pada penelitian ini adalah teknik purposive sampling. Teknik purposive sampling adalah teknik untuk menentukan seseorang dapat dijadikan sampel atau tidak yang didasarkan pada tujuan tertentu (Sukardi, 2013). Sampel diambil dengan karakteristik sebagai berikut 1) Memiliki tingkat pembelian impusif tinggi, 2)Pengguna instagram aktif dan 3) Pengguna Whatsapp aktif

Sampel dalam penelitian ini yaitu 7 orang mahasiswa FKIP Bimbingan dan Konseling semester 5B Universitas Bengkulu tahun ajaran 2020/2021. Peneliti menggunakan instrumen kuisioner (angket) dalam teknik pengumpulan data yang disebarkan melalui google form. Kuisioner pada penelitian ini menggunakan model skala Likert dengan lima kriteria dan alternatif jawaban.

Uji validitas dilakukan dengan dua cara yakni uji validitas isi dan validitas konstruk. Validitas isi dilakukan oleh tiga orang dosen Bimbingan dan Konseling. Sedangkan validitas konstruk dilakukan menggunakan bantuan software SPSS Versi 24. Item akan dinyatakan gugur apabila memiliki nilai $\mathrm{r}$ hitung $<0.30$. Dari 36 item angket sebanyak 4 item angket gugur dan menyisakan instrument sebanyak 32 item.

Uji reliabilitas instrumen dilakukan dengan menggunankan bantuan software SPSS Versi 24. Hasil uji reliabilitas menunjukkan bahwa nilai reliabilitas sebesar 0.9555. Ghozali mengatakan bahwa suatu variabel dinyatakan reliabel jika cronbach's alpha >0.7 (Muzakky, 2015). Sehingga 
dapat disimpulkan bahwa variable pada penelitian ini reliable karena nilai cronbach's alpha >0.7 yaitu 0.954 . Nilai uji reliabilitas dapar dilihat pada tabel 1.

\section{Tabel 1}

Hasil Uji Reliabilitas

\begin{tabular}{ccc}
\hline Cronbach's Alpha & $\begin{array}{c}\text { Cronbach Alpha Based on } \\
\text { Standardized Items }\end{array}$ & N of Items \\
\hline 0.954 & 0.955 & 32 \\
\hline
\end{tabular}

\section{Hasil Dan Pembahasan}

Pembelian impulsif secara online sangat potensial dilakukan (Rook \& Fisher, 1995). Apalagi semenjak diberlakukannya PSBB (Pembatasan Sosial Berskala Besar) aktivitas fisik di luar ruangan menjadi terbatas dan meningkatnya akses media sosial. Semakin sering seseorang mengakses media sosial maka semakin sering pula seseorang melihat promosi barang. Dengan tersedianya promosi penjualan tersebut konsumen akan melakukan keputusan pembelian (Rook, 1987). Media internet dengan kepraktisannya ini menjadi akses utama untuk melakukan pembelian impulsif (Rook \& Fisher, 1995).

Ada dua faktor yang mendorong terjadinya pembelian impulsif pada online shop yaitu faktor eksternal dan faktor internal (Miranda, 2016). Faktor internal yang mempengaruhi terjadinya pembelian impulsif di online shop yaitu suasana hati gembira atau emosi positif, jenis kelamin, keadaan financial, gaya hidup dan pekerjaan. Faktor eksternal yang mempengaruhi pembelian impulsif pada online shopping meliputi kualitas pelayanan dan promosi.

Pada penelitian ini layanan bimbingan kelompok diberikan sebagai bentuk upaya mengurangi pembelian impuslif. Layanan bimbingan kelompok ini dilakukan dengan berbasis cyber-guidance atau melalui perantara elektronik. Media yang digunakan untuk melakukan layanan adalah aplikasi WhatsApp. Pelaksanaan cyber-guidance melalui whatsapp ini menjadi alternatif pemberian layanan yang tepat dilakukan dalam masa pandemi. Layanan cyber-guidance ini dilakukan tanpa adanya kontak fisik sehingga dapat mencegah penyebaran virus covid-19.

Peneliti menggunakan teknik scalling dalam layanan bimbingan kelompok. Menurut Murphy teknik scalling adalah teknik yang membantu konselor dengan memberikan penilaian di angka 1-10 untuk membuat masalah kompleks tampak lebih konkret dan nyata (Erford, 2016). Solomon dan Rabolt (dalam Sari \& Faisal, 2018) mengatakan bahwa pembelian impulsif disertai dengan adanya dorongan kuat dan mendesak yang menyebabkan ketidakseimbangan psikologis pada diri seseorang. Dorongan yang kuat ini menyebabkan seseorang melakukan rasionalisasi terhadap barang yang akan mereka beli. Teknik scalling ini digunakan untuk membuat dorongan pembelian impulsif dan pemikiran yang kompleks menjadi lebih konkret dan dapat dikendalikan oleh klien.

\section{Tabel 2}

\section{Hasil Pre-test Pembelian Impulsif Mahasiswa}

$\begin{array}{llll}\text { Kategori } & \text { Rentang skor } & \text { Frekuensi } & \text { Persentase \% }\end{array}$




\begin{tabular}{cccc}
\hline Tinggi & $\geq 117$ & 6 & 85,7 \\
Sedang & $75-116$ & 1 & 14,3 \\
Rendah & $<75$ & 0 & 0 \\
Total & & $\mathbf{7}$ & $\mathbf{1 0 0}$ \\
\hline
\end{tabular}

Sebelum diberikan layanan bimbingan kelompok berbasis cyberguidance dengan teknik scalling mahasiswa diberikan angket untuk mengukur tingkat pembelian impulsifnya. Pada tabel 2 diketahui bahwa ratarata tingkat pembelian impulsif mahasiswa berada pada kategori tinggi. Dari 7 orang mahasiswa, 6 diantaranya berada pada kategori tinggi sedangkan 1 berada pada kategori sedang. Setelah diberikan instrument, kemudian 7 orang mahasiswa dipilih untuk diberikan bimbingan kelompok. Bimbingan Kelompok dilaksanakan sebanyak 6 kali pertemuan. Topik yang dibahas pada masing-masing pertemuan pun berbeda-beda.

Pertemuan pertama topik yang dibahas mengenai Karakteristik Pembelian impulsif. Pada pertemuan ini, mahasiswa melakukan diskusi mengenai pengertian pembelian impulsif, bagaimana bentuk pembelian impulsif pada kehidupan sehari-hari serta faktor yang mempengaruhi pembelian impulsif.

Pertemuan kedua topik yang dibahas yaitu pengaruh Instagram Terhadap Pembelian Impulsif. Pada pertemuan kali ini mahasiswa membahas bagaimana Instagram bisa menyebabkan seseorang dapat melakukan pembelian impulsif. Kemudian anggota diminta melakukan penskalaan mengenai seberapa besar pengaruh iklan di Instagram dalam mempengaruhi pembelian impulsif. Skala berada direntang 1-10 dimana 1 tidak terlalu berpengaruh dan 10 sangat berpengaruh. Jawaban dari anggota pun beragam ada yang menjawab 1 dan mayoritas menjawab di rentang 4-8. Setelah itu dilakukan lagi penskalaan untuk mengukur motivasi anggota untuk merubah perilaku impulisfnya. Hasilnya anggota kelompok rata-rata menjawab mereka ingin berubah diskala 2 . Teknik scalling pada pertemuan kedua ini dilakukan untuk mengetahui penilaian anggota terhadap dirinya sendiri, dan seberapa besar motivasi mereka untuk berubah.

Pada layanan ketiga topik yang dibahas adalah iklan dan tren. Pemimpin kelompok beserta anggota kelompok berdiskusi mengenai bagiamana iklan dan tren dapat menyebabkan pembelian impulsif. Pada layanan ketiga, anggota kelompok antusias dalam berdiskusi karena mereka merasa bahwa iklan dan juga tren mempengaruhi mereka untuk melakukan pembelian impulsif.

Pada layanan keempat, dibahas mengenai kebutuhan dan keinginan. Awalnya dibahas terlebih dahulu mengenai pengertian kebutuhan dan keinginan. Lalu dilaksanakan teknik scalling, teknik ini dilakukan sebanyak tiga kali. Penskalaan pertama dilakukan dengan meminta anggota kelompok membuat skala prioritas mengenai barang yang diinginkannya dari skala 1-5 dimana 1 yang sangat ingin dibeli dan 5 yang tidak terlalu ingin dibeli. Penskalaan kedua, anggota kelompok diminta untuk melakukan penskalaan mengenai barang yang mereka butuhkan. Kemudian, klien diminta untuk membuat skala prioritas mengenai barang yang mereka butuhkan tadi dimana skala 1 merupakan barang yang mereka butuhkan sedangkan 10 
barang yang tidak dibutuhkan. Hasilnya, anggota kelompok mulai meletakkan barang yang mereka butuhkan di skala no 1 .

Pertemuan kelima, materi yang dibahas adalah situasi potensial pembelian impulsif. Pemimpin kelompok meminta anggota kelompok untuk menyebutkan situasi yang dapat mendorong mereka melakukan pembelian impulsif untuk kemudian dibahas dalam kelompok. Setelah itu pemimpin kelompok juga meminta anggota kelompok mempraktekkan teknik yang diberikan sebelumnya jika mereka berada di situasi yang dapat memicu mereka melakukan pembelian impulsif.

Pada pertemuan terakhir, pemimpin kelompok meminta anggota kelompok untuk menyampaikan kendala yang mereka hadapi ketika melakukan penerapan teknik tersebut. Kemudian kendala yang disampaikan dibahas bersama-sama oleh anggota kelompok

Terjadi penurunan tingkat pembelian impulsif pada mahasiswa setelah diberikan layanan bimbingan dan kelompok. Dari tabel 3 diketahui dari 7 orang mahasiswa, 6 orang berada di kategori pembelian impulsif tinggi dan 1 orang berada dikategori sedang. Setelah diberikan layananan, dari 7 orang mahasiswa sebanyak 5 orang berada dikategori pembelian impulsif sedang dan 2 orang berada dikategori rendah. Ini menunjukkan bahwa terjadi penurunan tingkat pembelian impulsif pada mahasiswa sebelum dan setelah diberikan layanan. Nilai rata-rata pembelian impulsif juga mengalami penurunan, yaitu dari 132 menjadi 86.1

Tabel 3

Perbandingan Skor Pre-test dan Post-Test Pembelian Impulsif

\begin{tabular}{cccccc}
\hline Nama & $\begin{array}{c}\text { Skor Pre- } \\
\text { Test }\end{array}$ & $\begin{array}{c}\text { Kategor } \\
\text { i }\end{array}$ & $\begin{array}{c}\text { Skor Post- } \\
\text { test }\end{array}$ & $\begin{array}{c}\text { Kategor } \\
\text { i }\end{array}$ & $\begin{array}{c}\text { Penurunan } \\
\text { Skor }\end{array}$ \\
\hline AF & 142 & Tinggi & 103 & Sedang & 39 \\
AV & 149 & Tinggi & 99 & Sedang & 50 \\
AS & 143 & Tinggi & 62 & Rendah & 81 \\
SPG & 133 & Tinggi & 88 & Sedang & 45 \\
DR & 130 & Tinggi & 76 & Sedang & 54 \\
YP & 117 & Tinggi & 104 & Sedang & 13 \\
PA & 110 & Sedang & 71 & Rendah & 39 \\
Jumlah & 924 & & 603 & & \\
Terting & 149 & & 104 & & \\
gi & & & & & \\
Terend & 110 & & 62 & & \\
ah & & & 86.1 & & \\
Mean & 132 & & & & \\
\hline
\end{tabular}

Hipotesis penelitian yang berbunyi bahwa "Ada pengaruh pemberian bimbingan kelompok berbasis Cyber-guidance melalui WhatssApp dengan teknik scalling terhadap pembelian impulsif di Instagram pada mahasiswa semester 5B Bimbingan dan Konseling Universitas Bengkulu telah terbukti”. Hal ini dapat dibuktikan melalui hasil dari uji t yang memiliki nilai sebesar 9.744. Serta nilai signifikansi memiliki nilai sebesar 0.000 , yang artinya nilai $\mathrm{P}<0.005$. Maka hipotesis (Ho) ditolak dan (Ha) diterima. Dari hasil tersebut, dapat disimpulkan bahwa terdapat pengaruh layanan bimbingan kelompok 
dengan teknik scalling untuk mencegah pembelian impulsif mahasiswa Bimbingan dan Konseling semester 5B di Universitas Bengkulu

\section{Simpulan}

Sebelum diberikan layanan bimbingan kelompok berbasis cyberguidance via WA dengan teknik scalling, tingkat pembelian impulsif mahasiswa semester 5B Prodi Bimbingan dan Konseling tergolong tinggi. Hal ini dilihat dari hasil pre-test yang sudah diberikan. Tingkat pembelian impulsif mahasiswa menurun setelah diberikan layanan bimbingan kelompok berbasis cyber-guidance dengan teknik scalling. Penurunan tingkat pembelian impulsif dilihat dari hasil post-test mahasiswa. Tingkat pembelian impulsif mahasiswa mengalami penurunan yang signifikan setelah diberikan layanan. Dengan demikian, dapat disimpulkan bahwa dengan pemberian layanan bimbingan kelompok berbasis cyber-guidance via Wa dengan teknik scalling terjadi penurunan pembelian impulsif pada mahasiswa bimbingan dan konseling semester 5B Universitas Bengkulu.

Pemberian layanan dalam bimbingan dan konseling secara online dapat dilakukan sebagai langkah alternatif pemberian layanan bimbingan dan konseling sebagai bentuk pencegahan penyebaran virus Covid-19. Pemberian layanan bimbingan dan konseling secara online ini juga dapat dilakukan dengan menggunakan media komunikasi lainnya dengan tetap berlandaskan asas dalam bimbingan dan konseling, sebagai bentuk pengembangan layanan bimbingan dan konseling.

\section{Daftar Pustaka}

Amanah, D., \& Alwi, S. P. (2015). Pengaruh Promosi Penjualan (Sales Promotion) dan Belanja Hedonis (Hedonic Shopping) Terhadap Impulsive Buying Produk Matahari Plaza Medan Fair. Quanomic, 3(2), 10-18. https://doi.org/10.17605/OSF.IO/SBDE3

Erford, B. (2016). 40 Teknik yang Harus Diketahui Setiap Konselor (1st ed.). Pustaka Pelajar.

Fitriyani, N., Widodo, P. B., \& Fauziah, N. (2013). Hubungan Antara Konformitas Dengan Perilaku Konsumtif Pada Mahasiswa Di Genuk Indah Semarang. Jurnal Psikologi Undip, 12(1), 1-14. https://doi.org/10.14710/jpu.12.1.1-14

Ifdil, I., \& Ardi, Z. (2013). Konseling Online Sebagai Salah Satu Bentuk Pelayanan E-konseling. Jurnal Konseling Dan Pendidikan, 1(1), 15. https://doi.org/10.29210/1400

Indika, D. R., \& Jovita, C. (2017). Media Sosial Instagram Sebagai Sarana Promosi Untuk Meningkatkan Minat Beli Konsumen. Jurnal Bisnis Terapan, 1(01), 25-32. https://doi.org/10.24123/jbt.v1i01.296

Miranda, Y. C. (2016). Kajian Terhadap Faktor yang Mempengaruhi Impulse buying dalam Online Shoping. Kompetensi, 10(1), 63-76. http://journal.trunojoyo.ac.id/kompetensi/article/download/3424/253 3

Muzakky, F. (2015). Pengaruh Sel-Efficacy, Lingkungan Sosial dan Lingkungan Fisik Sekolah terhadap Prestasi Belajar Ekonomi Siswa Kelas XI IPS Babakan Lebaksiu Tahun Ajaran 2014/2015. http://lib.unnes.ac.id/23508/1/7101411170.pdf

Puspita, D., Elita, S., \& Sinthia, R. (2019). ISSN 2599-1221 (Cetak) ISSN 
2620-5343 (Online) https://ejournal.unib.ac.id/index.php/j_consilia. Onsila:Jurnal Ilmiah Bimbingan Dan Konseling, 2(3), 271-281.

Rahman Afandi, A., \& Hartati, S. (2017). Pembelian Impulsif pada Remaja Akhir Ditinjau dari Kontrol Diri. Gadjah Mada Journal Of Psychology, 3(3), 123-130.

Rook, D. W. (1987). 1987 Rook.pdf. In The Journal of Consumer Research (Vol. 14, Issue 2, pp. 189-199). Journal of Consumer Research.

Rook, D. W., \& Fisher, R. J. (1995). Normative Influences on Impulsive Buying Behavior. Journal of Consumer Research, 22(3), 305. https://doi.org/10.1086/209452

Sari, D. R., \& Faisal, I. (2018). Jurnal Sains Manajemen dan. Sains Manajemen Dan Kewirausahaan, 2(1), 51-60.

Sukardi. (2013). Metodologi Penelitian Pendidikan Kompetensi dan Prakteknya. Bumi Aksara.

Widawati, L. (2011). Analisis Perilaku "Impulse Buying" dan " Locus of Control" pada Konsumen di Carrefour Bandung. Jurnal Sosial Dan Pembangunan, 27(2),125132.https://ejournal.unisba.ac.id/index.php/mimbar/article/ view/320 